\title{
Urinary lithiasis induced by sulfamethoxazole in a patient with tetraplegia. Case report
}

\author{
M Rince, ${ }^{1}$ P Dudognon, ${ }^{2} \mathrm{C}$ Moesch,${ }^{3} \mathrm{C}$ Leroux-Robert ${ }^{4}$ \\ ${ }^{1}$ Praticien hospitalier, Service de Néphrologie, ${ }^{2}$ Professeur des Universités, Praticien \\ hospitalier, Service de Rééducation et Réadaptation Fonctionnelles, ${ }^{3}$ Docteur en \\ Pharmacie, Service de Néphrologie, ${ }^{4}$ Professeur des Universités, Praticien hospitalier, \\ Chef du Service de Néphrologie, Centre Hospitalo-Universitaire Dupuytren, 87042 \\ Limoges Cedex, France.
}

Bladder lithiasis is a frequent complication in paraplegics and tetraplegics. We report on a patient where treatment of a urinary infection with antibacterial sulfamides was the causative factor in the formation of bladder stones.

Keywords: paraplesia; urinary lithiasis; sulfamides.

A male patient aged 49 years was admitted with a flaccid tetraplegia of traumatic origin. This condition was accompanied by persistent urinary infection in spite of continuous treatment modified according to the results from bacterial culture and from sensitivity tests. The patient was predisposed to infection because of an indwelling bladder catheter, bed rest, diuresis of less than $1 \mathrm{~L}$, and chronic constipation.

$\mathrm{He}$ received $1600 \mathrm{mg}$ sulfamethoxazole (Bactrim Forte $(\mathrm{R})$ )/day for 10 days in conjunction with methylene blue. One month later, he received $1600 \mathrm{mg} /$ day for 5 days. Bactrim was again administered intravenously 4 months later (4 ampules of $400 \mathrm{mg}$ each/day) then orally $(800 \mathrm{mg} /$ day $)$ for 14 days.

Nine months following the trauma, after removal of the bladder catheter, bladder emptying was obtained by intermittent catheterisation. Urinary infection persisted without altering renal function. On several occasions, stones were observed upon removal of the catheter.

Eleven calculi, ranging from 1 to $5 \mathrm{~mm}$ in diameter, were analysed according to a previously described technique ${ }^{1}$ consisting of examining the surface and sections of the stones with a stereomicroscope and analysing the molecular composition by transformed FOURIER infrared spectrophotometry (IRTF BRUKER IFS 48 spectrophotometer). The calculi contained a bluegreen centre representing $60 \%$ of total dry weight and composed of $\mathrm{N}$-acetylsulfamethoxazole chlorhydrate, the principal urinary metabolite of sulfamide. This nucleus was covered with a mixture of uric acid $(35 \%)$ and calcium oxalate $(5 \%)$.

The first patients with urinary calculi containing sufamethoxazole were reported in 1977. ${ }^{2.3}$ Although sulfamethoxazole crystalluria is among the most frequent crystallurias resulting from medication, ${ }^{4}$ we have observed only 2 out of 1500 stones composed of this active principal. ${ }^{5}$ In the case reported here, treatment was directly responsible for the calculus because it forms the nucleus. $\mathrm{N}$-acetylsulfamethoxazole chlorhydrate is usually light beige. The blue-green colour seen is due to the methylene blue, whose presence is interesting because it marks the period at which Bactrim Forte $(\mathrm{R})$ had a direct role in nucleus formation (10 days treatment at $1600 \mathrm{mg} /$ day, orally).

The iatrogenic effect of the medication cannot be explained by an elevated dose. In fact, the mechanism for this stone formation seems to be due to urinary supersaturation caused by the low solubility of the metabolite, $\mathrm{N}$-acetylsulfamide. The presence of uric acid and calcium oxalate associated with the drug is not compatible with an infectious origin of lithiasis because ammonium magnesium phosphate or calcium phosphate should have been identified. The administration of sulfamethoxazole to patients having urinary stasis or a foreign body 
(bladder catheter, etc) should be avoided, or conditions should be optimised to obtain maximal solubility. The diagnoses of these calculi should be made as soon as possible, preferably with the appearance of the first stone, which then necessitates the implementation of appropriate analytical techniques.

\section{References}

1 Moesch C, Rince M, Raby C, Leroux-Robert C (1986) Résultats d'analyse physico-chimique de 324 calculs urinaires recrutés en Limousin. Ann Pharm Fr 44: 403-410.

2 Bülow H, Klee WE, Hotzel A, Frohmüller H (1977) Zur Frage einer Harnsteinbildung nach Trimethoprim/ Sulfamethoxazol-Therapie. Fortsch Urol Nephrol 9: 116-118.

3 Siegel WH (1977) Unusual complication of therapy with sulfamethoxazole-trimethoprim. J Urol 9: 116-118.

4 Daudon M, Reveillaud RJ (1986) Cristalluries médicamenteuses: mythes et réalités. Ann Biol Clin 44: 25-34.

5 Moesch C, Rince M, Raby C, Leroux-Robert C (1990) Données épidémiologiques sur les calculs rénaux analysés par I.R. dans la région de Limoges. Inform Scient Biol 16(2), 136. 